\title{
Writing of a Different Class? The First 120 years of Working-Class Fiction in Finland
}

Elsi Hyttinen \& Kati Launis

In I976, the magazine Suomen Kuvalehti published a feature item with the title "Pirkko Saisio's introspection: We are still waiting for the great working-class author." In the article, the young debut novelist reasons that "A working-class author is an author who depicts working people and their endeavours from the point of view of a worker. . . As for me, for the time being I lack both the political awareness and the first-hand knowledge of a present-day worker's life and mindset required of a person who should wish to call themselves a working-class author" (Saisio, I976).

Pirkko Saisio's novel Elämänmeno [The Course of Life] (I975) follows its protagonist, Marja, from childhood to early adulthood, with a class awakening as the central focus. Together with a fierce-tempered mother and a good-natured stepfather, Marja lives in a bedsit in Kallio, a distinctly working-class neighborhood in the Finnish capital, Helsinki. Saisio chose to locate Marja in a milieu of which she had first-hand knowledge; the author herself had lived in Kallio the first few years of her life, before moving to a new, respectably middle-class suburban housing development in the eastern outskirts of the city. Saisio was already a theater school-trained actor at the moment of the novel's launching, but the novel's public was eager to see the protagonist as her alter ego. This is a curious phenomenon, perhaps explained by the fact that, in the I970s, most of the reading public would have defined a working-class author the same way as Saisio herself does in the citation above. In its eagerness to greet the arrival of the great

How to cite this book chapter:

Hyttinen, E. and Launis, K. 20I7. Writing of a Different Class? The First I 20 years of Working-Class Fiction in Finland. In: Lennon, J. and Nilsson, M. (eds.) Working-Class Literature(s): Historical and International Perspectives. Pp. 65-94. Stockholm: Stockholm University Press. DOI: https://doi. org/IO.I6993/bam.d. License: CC-BY 
working-class author, the reading public chose to ignore Saisio's education in arts and, instead, substituted her life events with those of her protagonist. Thus, Marja's fictional childhood experiences came to serve as a proof of Pirkko Saisio's rough childhood and first-hand experience of the living conditions of the working poor. To facilitate this transferal, interviews of Saisio were sometimes accompanied by a photograph of the author standing outside the Kallio block of flats that she and Marja shared (Hyttinen, 2004).

Twenty-five years later, in an autobiographical essay, the author revisited her memories of the mid-I970s' debate: “Elämänmeno's reception was positive, overwhelming, even, slightly dangerously so for a young writer. I was offered the boots of a great working-class author, they were fiercely jerked from me, and then tried on my feet again. The words flew high above and by me, like in the ceremonies of the J. H. Erkko prize for first novels where the dispute over my possible status as a working-class author was so heated that I, understanding nothing of the arguments and the aggression, had to flee for shelter in the toilets out of sheer nervousness" (Saisio, 2000, p. 353). There is something very historically specific about the image of a writer hiding in the bathroom as a heated dispute over the concepts of working-class literature and authorship is carried out in her name. The I970s in Finland was, after the all-around cultural radicalism of the I960s, a decade of serious attempts at bringing together class-awareness, political commitment, and art-hence the desire to find an author in whose figure all three would meet.

On the other hand, there is also a notably non-historically-specific side to the anecdote: in addition to illustrating the nature of the r970s cultural debates, it captures an essential defining feature of the Finnish working-class literary tradition as a whole. The writers of this article claim that, in Finland, there is not really a tradition or a canon of works that could unproblematically be referred to as the working-class tradition. Rather, there is a tradition of uneasiness and heated debate provoked by every attempt at pinpointing such a continuum. What is, can, or should be considered as working-class fiction has been disputed for more than a hundred years already, with no end in sight. 
Whereas in some other areas of the world debates have perhaps formed around aesthetics as a defining feature of workingclass fiction, in Finland the arguments always return to "reality." Generation after generation, the question is raised: Is this truthful? Working-class literature is expected to be a truthful depiction of a worker's worldview, which, as it happens, is supposed to naturally be concordant with socialist class theories. To make this articulation look natural, the debaters have time and again turned to the figure of the author. Granted, certain types of books are more likely to trigger the debate and the uneasiness than others. Whether or not discussing these trigger-books in chronological order is the same thing as writing a Finnish working-class literary history is, perhaps not entirely surprisingly, up for debate.

\section{Two Fields of Literature, 1895-1918}

It is impossible to talk about Finnish working-class literature (or working-class writers, or to even ask if a writer is or is not a working-class writer) in a worthwhile way before the turn of the twentieth century. As Raoul Palmgren (r966 a \& b) and Aimo Roininen (I993) have shown, Finnish working-class literature only emerged at the same time as the Finnish labor movement and labor press. This, in turn, coincides with the global upsurge of working-class literary culture. Especially interesting in this respect is the rise of working-class literature in Russia, as Finland, in fact, was a part of the Russian empire from I 809 to the Finnish declaration of independence in December I917. Even though the developments in Moscow, Saint Petersburg, and Helsinki follow similar patterns (see Clark in this anthology), they do not form a single literary movement. The Finnish and Russian languages are entirely different from each other, so most Russian influences necessarily underwent translations, both linguistic and cultural. Maxim Gorky is known to have had a considerable impact on some Finnish writers (Roininen, I993, pp. 21 2-224), both as a role model and a personal acquaintance. Further, reviewing Gorky gave the Finnish press an opportunity to articulate its ideals and cultural politics in the very first years of the twentieth century when very little original Finnish working-class literature yet existed 
(Roininen, I993, p. 216). However, many of the transnational connections of the Finnish field still remain underresearched. ${ }^{\text {I The }}$ dominating frame for research on Finnish working-class culture has been a national one, which means that even the birth of our working-class literary culture has been predominantly explained as a consequence of the developments and turns in Finnish national politics. Subsequently, much less critical effort has been put into locating the Finnish field within a larger inter- and transnational framework.

As established in Raoul Palmgren's pioneering work Joukkosydän [The Collective Heart] ${ }^{2}$ in the r960s, it is now a commonly shared understanding that the first generation of Finnish working-class writers consists of approximately I 70 writers. However, Palmgren makes a point of specifying that only a fraction of them came from a working-class context and thus met his own criteria for proper working-class authorship (Palmgren, 1965, pp. 222-223).

A renewed interest in early Finnish working-class literature begins in 1993 with the publication of Aimo Roininen's Kirja liikkeessä [Book in Movement], in which focus is shifted from the individuals to the structures supporting them and, thereby, makes their agency possible. Indeed, its subtitle reads "Literature as institution in the old working-class movement." Roininen's work has been inspirational to the generation of researchers that the writers of this article represent, as it offered a new way of delineating the limits of the phenomenon studied. No longer was it necessary to presume a unifying worldview or shared horizon of experiences for all working-class writers. Instead, one could focus on how different writers were located institutionally.

The writers who formed the emerging network of Finnish working-class literature came from different strata of the society but shared an interest in creating an alternative to bourgeois culture. Here again, Finland is no exception in the global context. As Gustav Klaus has argued, within working-class literature, writers born in the working class are rare. In his view, writers not born into the working class have contributed massively to the formation of "literature of labour" everywhere (Klaus, I98 5, p. ix; Hitchcock, I989, p. 7). Early Finnish working-class writers formed 
a heterogeneous group with their different backgrounds, used different literary genres, and published in both official languages, Finnish and Swedish. In Finland, Swedish was the language of the educated classes all the way to the 1870 , when the Finnish language began to rise as a language of literature. There were writers such as the playwright Elvira Willman, with her university education and roots in a family of shipowners, and Hilja (Liinamaa) Pärssinen, a teacher and the leader of the Women Workers' Union in Finland. And there were writers from lower classes-such as Kössi Kaatra, the decadent bohemian Kasperi Tanttu, the prosaist Konrad Lehtimäki, the bohemian poet and lay preacher Esa Paavo-Kallio, and the Swedish-speaking Arvid Mörne. (Hyttinen, 20I 5, p. 60; Palmgren, I966a, p. I78).

Thus, not all writers who wrote working-class literature in the early years of the twentieth century had their roots in the lower classes. Conversely, quite a number of writers publishing on what research later has called "the national" or "the bourgeois" field of culture did (Hyttinen, 20I 5, p. 60). The social stratum of the intelligentsia was quite narrow: there were way too few educated upper-class families in the country for them to be able to provide the modernizing nation with all the teachers, academics, writers, critics, politicians, journalists, and other public figures it needed. The new intelligentsia came from all levels of society: upstarts flourished (Rojola, 2009). The son of a working family could, given the right twists of fate, end up as a "mainstream" poet, with nothing in his writing being an evident reminder of his roots. In our understanding, the change that took place at the beginning of the twentieth century had first and foremost to do with a reorganization of the literary field. However, whether or not working-class writers should ideally emerge from a proletarian background-or whether a dedication to the cause of the working class would suffice to turn an intellectual from the educated classes into a legitimate contributor to the working-class field of culture-has remained a hot topic, in Finland as elsewhere (see Clark and Nilsson in this collection).

The earliest examples of Finnish working-class literature were published in newspapers and journals. Most often, they consisted of poetry, but other short forms, such as stories and causeries, flourished as well. The newspapers and journals were mostly 
owned by organizations of the workers' movement and bore names such as The Worker [Työmies] (I895-I91 8, the first Finnish working-class newspaper); A Worker's Soiree [Työmiehen illanvietto] (I902-I906, a literary magazine); and the People's Will [Kansan tabto] (I906, a newspaper). Publishing in them signaled a strong desire to take part in creating the alternative field of working-class literary culture. No writer with bourgeois aspirations would have chosen them as the primary outlet for their writing.

Furthermore, a number of working-class writers wrote directly for the stage (Roininen, I993, p. 298), as theatre was a popular working-class pastime. Especially in Helsinki, the working-class amateur theatre scene was vivid, and the National Theater offered workers cheap tickets for the third balcony, as well as whole shows at subsidized prices (Seppälä, 20I0, pp. 20-27). It has been claimed that theatre was more easily accessible for the working people than books because theater, as a form, did not require as much free time and solitude as reading novels. Also, publishing a novel would have almost inevitably, regardless of their aspirations, marked the author as an agent of the bourgeois cultural field since there were yet no publishing houses run by the working-class movement or people at the time (Hyttinen, 20I2, pp. 52-56). This uneasiness with book-reading is even thematized in working-class playwright Elvira Willman's I903 debut, Lyyli (which premiered at the National Theater), where reading dangerously detaches a working-class girl from her class position but, in the end, does not grant her access to the higher rungs of the class ladder (Hyttinen, 2OI 2, pp. 36-4I). Only in the I9IOs did the first story collections and novels written by working-class authors become available to audiences (Roininen, I993, p. 307). The rise of the working-class press had created a string of small presses that acted as publishing houses as well, and no longer were the bourgeois establishments the only ones available for aspiring fiction writers (Roininen, I993, pp. 369-373).

As dramatically convincing as Willman's class-conscious reutilization of the trope of dangerous reading (made known by Gustave Flaubert's Madame Bovary [1 8 56]) was, the fact remains that Finnish workers did read novels and other longer forms, even if domestic working-class writers did not initially write in those 
genres. As literary historians have shown, in Finland the most popular and widely read literature at the end of the nineteenth century was religious (Luukkanen, 20I6, pp. 42I, 458), and the most borrowed book from libraries was the Bible (Kotilainen, 20I6, p. 208). However, towards the end of the nineteenth century, the situation changed when the number of folk libraries and, soon after, working people's libraries began to increase as an outgrowth of the powerful breakthrough of the working-class movement. These developments made a large selection of books widely available. By 191 6 there were over I,000 workers' libraries in Finland, with almost I००,००० volumes available for borrowing (Roininen, I993, p. 72).

It should be emphasized that, even when perceived within the national container, working-class literature was not born out of nowhere. It was not an isolated island of its own but part of a wider literary tradition. Raoul Palmgren (I966a, p. 5) has argued that there is "a red strand" in Finnish literature since its very beginning of folklore origins. In particular, the realist author Minna Canth (I 844-I 897) was a favored role model for working-class writers. But writers before Canth (such as J. L. Runeberg [г 804-г877], regarded as the Finnish national poet in the nineteenth century) had depicted poor, common people. Working-class writers, however, re-wrote this earlier, Runebergian, idealistic tradition, rejecting his conception of a submissive people and replacing it with that of defiant citizens (Launis, 2009, p. 98). During the nineteenth century and before the rise of the working-class movement, there were also self-educated writers (or "common" people with very limited formal education) who represented the working people and the landless country population. For these nineteenth-century peasant writers in rural Finland, writing was a new technology, the implications of which manifested themselves in several meta-poetic ways. For example, in their texts, they often included apologies for poor writing and lack of poetic sensibilities. These writers, who lived in a semi-literate society, have been rediscovered and have become a topic of multidisciplinary research during the past ten years (Kauranen, 2013; Kuismin, 2016).

Until the early twentieth century, as research shows, the public sphere in Finland had been relatively uniform (Haapala, I999, 
pp. 2I4-I6; Lahtinen, 2006, pp. I 50-54; Nieminen, 2006, p. I60) and tightly connected ideologically to nationalist interests. Only at the end of nineteenth century do we witness a quick erosion of such national monoculture. The emergence of the working-class cultural field was but one outcome of the process. An extremely important year for that "other publicity" emerging around the working-class movement was the year I 895-when the first newspaper for workers, Työmies [The Worker], was founded. Only a few years earlier, at the beginning of the I890s, it was strongly questioned whether there would be any writers or readers for working-class publication. As Lappeenrannan uutiset (I895) chronicles in retrospect,

Doubts were raised as to whether there was enough workforce available for putting together working-class literature of some kind, and, what is more, whether the poor workers of Finland had the means for supporting the endeavour enough so that the initiators would not suffer a financial loss. (Lappeenrannan Uutiset, I7 July I 895.)

These doubts notwithstanding, Työmies appeared in 1895 and was soon followed by other newspapers. The earliest hit in the Finnish National Library's Digital Collection of Newspapers using the search term työväenkirjallisuus [working-class literature] is from the same year, I 895 (Lappeenrannan Uutiset, I7 July I 895), and the first hit for the Swedish term arbetarlitteratur [working-class literature] is from the year I903 (Vasabladet, 22 September 1903). The first real debate in the Finnish press on the definition of the term working-class literature (the debate that, as we argue in this article, still continues) took place in I904 in Työmies. Edvard Valpas, the editor-in-chief of Työmies and an influential theorist of Kautskyan socialism in Finland, rejected Kössi Kaatra's poems in his article “Työväen laulaja” ["Workers' Singer"], even though Kaatra was widely regarded as the "court poet of the movement." And, in the same vein, Valpas presented a theoretical introduction to the concept of working-class literature. According to Valpas, the Finnish society of the era was not yet at the stage where real, fully-developed socialist art is possible. In his poems, Kaatra did not (according to Valpas' dire judgment) manage to measure up to the ideals of working-class literature. His poems were not ideological enough and their forms were not 
advanced enough. For Valpas, they were suspiciously individual and genteel (Valpas, I904). It should perhaps be stated here that, among his contemporaries, Valpas represented the most extreme Marxist and materialist view on literature (Roininen, I993, pp. IOI-IIO, 377-399).

\section{Transnational Influences}

The year I904 seems to mark a coming of consciousness of the Finnish working-class literary field. Suddenly, working-class newspapers start publishing, on different occasions, lists of "the most famous working-class writers in our country" 3 - consisting of names such as Santtu Piri, N. R. af Ursin, Lauri Soini, Hilja Liinamaa, and Kaarlo Luukkonen. Thus, the alternative field begins its own canon formation, expressing which writers are part of "us," and what kind of literature is good and recommendable for the working-class readership (Roininen, I993, pp. 34-37).4 Around the same time, working-class literature emerges as a critical term in Russian and Swedish labor movements as well (see Clark and Nilsson in this collection).

The Scandinavian and, to a degree, the Russian and AngloAmerican literary developments were closely followed in the Finnish working-class press (Roininen, I993, pp. 269-284). Literature from other countries, such as Germany and France, was written about as well, but more sporadically (Roininen, I993, pp. 284-297). The majority of Swedish writers the Finnish-language press wrote about-such as Rudolf Björnsson, Martin Koch, Maria Sandel, Elin Wägner, Gustaf Fröding, and Selma Lagerlöf-were either working-class writers or wrote about subjects presumed to be of immediate interest to a working-class readership (Roininen, I993, p. 265). The Swedish-language working-class press in Finland went even further by following the developments of the Swedish working-class literary field. As working-class literary production in Swedish was scarce on this side of the Baltic Sea, the Swedish-language papers filled their cultural pages with reviews of Swedish working-class writers. This development begins around 1905, and during the I9I0s approximately forty Swedish writers were discussed. Moreover, the papers did not 
only follow working-class fiction but also covered, from a classconscious perspective, cultural debates carried out even in Swedish mainstream newspapers-introducing their readers to critics such as Bengt Lidforss, Torsten Fogelqvist, and C.A. Bolander (Roininen, I993, p. 268).

In addition to discussing their contemporaries, Finnish intellectuals also turned their eyes toward the past decades of Nordic literature. While the I 88 os' realists August Strindberg, Henrik Ibsen, and Bjørnstjerne Bjørnson were eagerly written about, it was the realist and social critical plays that were favored (Roininen, I993, pp. 226, 269). These authors were not regarded as working-class writers, but their production was something over which class-conscious debates could be articulated. All in all, the Swedish working-class literary development was keenly followed in the Swedish-speaking Finnish press. In contrast, the coverage of Swedish working-class literature was more sporadic in the Finnishspeaking press. Quite understandably, the main focus in the Finnish-language press was on Finnish writers writing in Finnish.

Leo Tolstoi, Maxim Gorky, and Leonid Andrejev were the Russian writers most favored by the Finnish working-class movement. In Finland, their works were most often brought to the market by working-class publishers, or through cheap series by bourgeois or commercial publishers, aimed at the general public with low income. Also, working-class newspapers and journals offered a significant channel for the translations to be published as serial stories (Roininen, I993, p. 212). American literature was of particular interest to the Finnish readership, partly because of the mass migration from Finland to the United States at the turn of the century. People were eager to get a feel of what it was like across the ocean. The most renowned names were Jack London and Upton Sinclair (Roininen, I993, pp. 269-270). However, the cultural debates in Russia and the United States were not systematically followed by the Finnish working-class press. These literatures were first and foremost represented as translations of fictional works.

The press was, of course, not the only arena where what it meant to be a working-class writer was defined. As Jürgen Habermas has famously argued, novels also formed part of national public spheres as they emerged in the nineteenth century. Fiction thus 
offered a cultural arena even for "making" and valuing the working class in a dialectical relationship with the upper classes and through processes intersecting with gender, sexuality, and nationality. In fiction, what it meant to be a working-class author could be thematized, analyzed, and defined. Kössi Kaatra, for example, depicts in his autobiographical novel, Äiti ja poika: Kuvaus köyhäinkorttelista [Mother and Son: A Picture of the Quarter of the Poor] (1924), the process of becoming a working-class poet. For him, a working-class writer is a "poet of the masses." To become a working-class writer in Kaatra's novel, one has to receive two "visitors." The first visitor incorporates the idea that people from the "poor quarters" are not alone but belong to the working class. The second visitor is the Muse, or the spirit of poetry. Their visits help a poet to realize that the private sorrows of an individual are not enough to form the contents of poetry; a working-class poet needs to express the feelings of the entire working class, from the "viewpoint of the back yard" (Launis, 201 5, pp. I4-34).5 This is something that became a distinctive mark of working-class literature for Kaatra and, more generally, for the whole movement. This definition is remarkably close to the one given by Pirkko Saisio in the I970s, quoted in the beginning of this article, which testifies to the extent to which most twentieth-century definitions are, in the end, versions of older understandings of culture as reflecting the social situation in which it is born.

While in the United States working-class literature has always been about the production of a class identity through modes of racial looking, as Balthaser shows in this anthology, in Finnish working-class literature class is strongly gendered. The ratio of the writers' gender alone is a good indicator of this: of the writers mentioned by name or pseudonym by Palmgren (I966b, pp. 535-536), I 66 were men and only I I were women (and of these women Maiju Lassila was known to be a pseudonym used by Algot Untola, a male writer). Furthermore, the most famous of the women writers in the fieldHilja Pärssinen, Elvira Willman, and Hilda Tihlä—came from the educated classes (Launis, 2009, p. 85). One explanation given for the low number of women writers, especially those with proletarian roots, is that they already had an outlet for their creativity in handwritten newspapers, which were popular in the societies of young 
working-class people (Salmi-Niklander, 20IO, pp. 20-4I). Another explanation is that these writers were occasionally hiding behind collective nicknames (Hyttinen \& Salmi-Niklander, 2008). Finally, a more direct explanation would be that, in a society that generally allotted most of the space to bourgeois men, it was difficult for women to make a name for themselves as writers. This was especially the case for lower-class women, since raising "the woman question" was often difficult and the highlighting of this inequality posed a potential threat to class cohesion and unity.

The coexistence of the two literary fields, the bourgeois and the working-class, came to a violent end in I9I 8, when the Finnish civil war broke out. The previous December (I9I7), Finland had gained its independence from Russia. The papers were signed by Lenin, and the agreement was reached through negotiations only and without violence, with the First World War and the Russian Revolution as a backdrop. However, during the final years of Russian rule, the class conflict in Finland deepened. ${ }^{6}$ Gaining independence opened up the question as to who should lead the country and by what means. The civil war began on 27 January I9I 8 and lasted approximately four months, until I5 May. It was a desperate undertaking, as neither side really had a strategy. Also, materially, in terms of equipment and weaponry, the Red front was much weaker than the White to begin with. The White front was right-wing, but it also represented the establishment. The existing infrastructure and clergy was regarded as being in their camp. The Red front was the revolutionary one, hoping to take over the state apparatuses. On both fronts, there were approximately 80,000 soldiers. Soviet Russia helped the Reds with arms shipments; the Whites received support from Germany. The support was tangible, as around I0,000 German soldiers fought alongside the White troops. ${ }^{7}$

Some working-class writers joined the Red troops, others took part in agitation, trying to keep up the spirits and unity of the Reds. After the Whites won the war, most writers associated with the Red front fled to Soviet Russia (or Sweden, like the above mentioned Kössi Kaatra), while some faced execution. Publishing houses were shut down. Even the make-ups, props, and wigs belonging to the working-class amateur theatres were redistributed to groups with ties 
to the right (Seppälä, 20Io, pp. I29-130). Granted, the absolute silencing of working-class culture did not last long. Already as early as I9I9, publications were distributed and some theater groups were rehearsing again (Seppälä, 2010, pp. I33-138). However, working-class culture never again established itself as an institutionally independent field the same way it had done during the first decades of the twentieth century. Rather, the bourgeois and working-class literary fields merged into one in which the battle over space, authority, and hegemony is constantly being fought.

\section{Working-Class Writers in the Young Republic}

After the Civil War in I9I8, the literary field in Finland was almost completely controlled by the victorious Whites. In fiction, the Civil War was mostly depicted from the point of view of the winners (Koskela, I999, pp. 222-239). The labor movement was divided into the reformist Social Democratic Party and the more radical Socialist Labor Party: instead of being just writers of the working class, working-class authors were, in this new cultural and political reality, forced to take sides in this political division of the left. However, not all writers wanted to conflate writing about the working class, and seeking a working-class audience, with party politics. This led to a new kind of configuration of authorship on the continuum of Finnish working-class literature. The term "leftist author" was coined as a means of surpassing the party-political divide and highlighting the artistic freedom of even the authors committed to the cause of the working class (Roininen, I999, pp. 240-24 I; Pynttäri, 201 5, p. I28). Workingclass literature was thus redefined as counter-hegemonic literature: not directly connected to party organs on either corner of the left field, but clearly antagonistic with regard to bourgeois values, politics, and literature. It is worth noticing that here, again, it was the author that had to be renamed, and all other changes on the cultural field negotiated through this renamed figure.

The I920s was a period of cultural modernism in the spirit of "the windows open wide to Europe," to quote the motto used by the most influential literary group of the era: Tulenkantajat [Torch bearers]. Yet it would not take long for Finland to develop 
into a patriotic, right-wing society. Under the threat of war in Europe and the fear of the communist Soviet Union, laws were enacted that prohibited communism and its propagation, with the aim to deter extreme leftist activities as well as to prevent any contact with the Soviet Union the Finnish left might have. In this complex situation, a small faction of left-wing intellectualsRaoul Palmgren, Jarno Pennanen, Kaisu-Mirjami Rydberg, Maija Savutie, Elvi Sinervo, Cay Sundström, and Arvo Turtiainenbegan their battle against the bourgeois cultural elite. In I936, this coalition of authors and artists founded a literary group known as Kiila [Wedge] (Salmi-Niklander \& Launis, 20I 5, p. 7; Koivisto, 2015 , pp. 99-I24), and proudly claimed in their first yearbook that only now was the working man for the first time in Finland entering the literary field as both subject matter and producer of literature (Turtiainen, I937, p. 7).

Indeed, literary scholar Veli-Matti Pynttäri points out that the rise of working-class literature in post-Civil War Finland was again accompanied by an increased critical interest in the notion of the working-class author. In I936, Kirjallisuuslebti, a leftist literary magazine, published an account of a social evening attended by members of Kiila, where the main topic of discussion was the notion of the working-class author on a general level. However, attention soon focused on the question of who, among the contemporary writers, could be considered a "real" working-class writer (Pynttäri, 20 I 5, p. I 25). The opposing views centered on one author in particular, Toivo Pekkanen, who was born into a working-class family and rose from rather poor conditions to become a nationally recognized author. In fact, Pekkanen was eventually granted the honorary title of an Academician in I955. Nonetheless, it was a shared opinion of Kiila activists that Pekkanen was not a working-class writer because he did not depict a typical proletarian. For example, in his autobiographical novel, Tehtaan varjossa [In the Shadow of the Factory] (1932), he portrayed an individual withdrawing from questions of social class into self-examination (ibid., pp. I26-I27). One year earlier, in I935, Raoul Palmgren, the leading ideologist of the group, had defined proletarian literature through three characteristics that he was-more or less—-to maintain throughout his career as 
a literary scholar: (I.) it must reflect proletarian vitality, (2.) it expresses a proletarian worldview, and (3.) it has a proletarian sphere of influence. Based on these criteria, Palmgren tended towards the exclusion of Pekkanen from the scope of proletarian literature on the basis of his "ideological indeterminancy"; his characters detach themselves from their social class and assume more individual concerns regarding human life. Palmgren returned to depict Pekkanen's working-class authorship in his later works. According to Pynttäri, Palmgren had a difficult, career-long relationship with Pekkanen (Pynttäri, 201 5, pp. I33-I38).

During the Continuation War (between Finland and the Soviet Union I94 I-I944; after the Winter War I939-I940), key members of the left-wing intelligentsia were imprisoned on charges of desertion and high treason, while many others were taken into what was called "preventive detention." After Finland lost the Continuation War, the political situation changed. Once the anticommunist laws were repealed in I944, the Finnish Communist Party could function legally, and many of the left-wing writers and intellectuals joined either it or the SKDL (Finnish People's Democratic League). The left-wing intellectuals were unique in their own generation in terms of their internationalization, based on their universal sense of solidarity with their co-ideologists (Koivisto, 20I 5, pp. 99-I 24).

In post-war Finland, one of the most influential writers was, without a doubt, Väinö Linna. He adopted the perspectives of ordinary men on the front during the Continuation War of I94 I-I944 in Tuntematon sotilas [The Unknown Soldier] (1954) and the turnof-the-century crofters who chose the side of the Reds in the I9I 8 Civil War in his Täällä Pohjantähden alla [Under the North Star] (I959-I962). Both novels were unprecedentedly successful. Linna himself had working-class background. He worked in a factory and depicted in his literary works a country in which everybody worked (see Ojajärvi, forthcoming). He retraces the movement from a rural society into an industrialised, modern North European nation state that firmly believed in the growth of the economy. He also was, together with Lauri Viita, for example, part of the group of the working-class writers called “Mäkelän piiri.” And yet, Linna's work was published by a mainstream publishing house and has been 
characterized as "probably the last representative of the Finnish national literature" (Nummi, I999, p. 99).

Väinö Linna did not like the notion of a working-class writer, neither personally nor in a broader sense. In I948, the leading newspaper in Finland, Helsingin Sanomat, presented Linna as probably "the only hundred-per-cent working-class writer in Finland." The next year, the authoritative critic Toini Havu stated in the same newspaper, referencing the ideas of the Swedish writer Folke Fridell, that working-class writers should describe workers' lives and factory work. Havu argued that writers should stay within their own sphere and focus on "normal workers," not on the exceptional ones. Väinö Linna critically responded to Havu's assertions, contending that, for him, the concept of a working-class writer (or, actually, the whole system of labeling writers) was a horror. The mission of a writer was "to find his own personality, to construct and fulfill it." The writer should not see human beings as "class-creatures"; the writer is not a politician (Varpio, 2006, pp. 227-23I). Linna continued this line of thought in the essay “Työläiskirjailijoista ja heidän tehtävistään” ["On Working-Class Writers and Their Missions"] (I949), in which he strongly emphasized the importance of the unique, personal view of every writer. Ironically, he repudiated the entire concept of a working-class writer because "it doesn't give many names to a dear child but one name to many children” (Linna, I990/I949, p. I 85$).{ }^{9}$ Even though he disentangled his work from the strict labels, he did not deny the importance of the social mission or task of literature (Linna I990/I964).

\section{0s and 1970s: History Revisited}

The I960s mark a turning point in the Finnish national self-understanding with regard to the working-class movement. The publication of the second part of Väinö Linna's three-volume novel suite Täällä pohjan tähden alla [Under the North Star] in I960 triggered an unforeseen discussion about the I91 8 Finnish Civil War and the events leading to it. Up until then, the civil war had often been referred to as the liberation war [vapaussota], and the victory of the Whites had been dubbed as victory over 
Soviet Russia. Now, Linna's depiction of the peasants, workers, and other minor characters forming the Red troops brought about a whole flood of memories thus far repressed from the public sphere. Many national memory organizations such as the People's Archives, Labor Archives, and the Literary Archives of the Finnish Literature Society started collecting memory data about the war from the point of view of the common people, from either side of the front but with a focus on micro rather than macro history.

It might be debatable whether or not Linna was a working-class writer and according to which criteria; his role as someone who gave form and language to a whole new way of understanding the Finnish national past, however, is not. The public debate surrounding the second part of the North Star trilogy also created pressure on historical scholarship (Kettunen I990, pp. I83 \& I9 I; Nummi, I999, p. I00), and it was only during the I960s that the first non-biased studies on the civil war and the birth of the Finnish nation state were written.

During the same decade, in I965, Raoul Palmgren defended his doctoral thesis on the concept of working-class literature, thus beginning the academic research tradition of the history of Finnish working-class literature. In his thesis, Palmgren discusses two words that had previously been used interchangeably as synonyms. Both translate into English as "working-class literature": työväenkirjallisuus and työläiskirjallisuus. ${ }^{10}$ Palmgren suggests that the first should be understood as a larger umbrella under which all kinds of literature aimed primarily at working-class audiences would fit, and the latter as literature produced by, aimed at, and expressive of the working class. The following year (I966), Palmgren published his two-volume study on pre-independence Finnish working-class literature (Palmgren, I966 a \& b), putting his theoretical concepts to use.

Palmgren saw a writer's proletarian roots and origins as a defining feature for työläiskirjallisuus. For him, true working-class literature is literature written by the working-class, expressive of the "working-class worldview," rough, untamed in form, and even clumsy at times (Palmgren, I965, pp. 222-223). The weakness contemporary research has been eager to point out in this formulation 
is that Palmgren seems to suggest that certain aesthetic features are caused by a writer's living conditions. This causal logic fits his Marxist understanding of culture as a superstructure reflecting the underlying division of labour in a society. However, this framework also allows him to view his favored forms, plotlines, and subject matters as being authentic expressions of a working-class worldview and to disregard others as being untrue (Hyttinen, 20I 5, pp. 59-60).

Palmgren was not the only one, of course, to try to find expressions of an authentic working-class worldview in the literature of the I960s. However, it is not until the r970s that this endeavor became one of the leading motives in cultural debates, as we saw in the opening anecdote of this article. Researcher Milla Peltonen claims that the two sensations surrounding the writer Hannu Salama are illustrative of the difference between the decades.

In I 964, Salama, whom Peltonen (201 5, p. I 67) calls "the bestknown but also the most controversial Finnish working-class author" of the I960s and I970s, wrote a novel titled Juhannustanssit [The Midsummer Dance] that brought upon him charges of blasphemy. In the novel, a drunken character indeed gives a mock sermon and, thus, quite openly questions, and laughs at, the Christian values of r960s Finland. That a novelist was charged with blasphemy was rare, as only a few cases were raised with regard to fictional literature during the whole of the twentieth century. Salama was sentenced to three months' imprisonment but was later pardoned by President Urho Kekkonen (Peltonen, 20I 5, p. I67). This first sensation was thus about the conservative society defending its values through state organs such as the court and the prison. Indeed, the radicalism of the I960s has been described as general radicalism against the establishment. That the radicalism should have more or less articulated political aims was a thing of the I970s (Niemi, I999, pp. I 58-I7I).

In I972, Salama's novel Siinä näkijä missä tekijä [ Where There's a Crime, There's a Witness] triggered the second public brouhaha of Salama's career-this time about how the working-class should be depicted. The debate resonates with Palmgren's conviction that a certain objectively definable working-class worldview exists that could and should be expressed in literature. This time, the 
sensation was not about the state against a rebellious individual, the debate is more correctly located within the cultural field and has to do with questions of authenticity and representability in regard to the working-class subject. Also, this time, it was not the establishment reacting to Salama's novel, but the left. As Milla Peltonen explains,

Since the mid-I960s there had been a major conflict on the left and inside the Communist Party of Finland (SKP). The party was led by the Eurocommunist Aarne Saarinen, who had begun to modernize the party line, but a minority of members rejected this and accused the SKP leadership of revisionism. The pro-Soviet internal opposition group was also known as "Taistoists," after their leader Taisto Sinisalo. Those literary critics who supported Saarinen mainly welcomed Salama's book, as did a majority of Social-Democratic and right-wing critics. . The Taistoist critics, in contrast, along with some veterans of the resistance movement, rejected the novel and publicly expressed their disappointment. Siinä näkijä missä tekijä, they claimed, was untruthful and pessimistic. (Peltonen, 20I 5, p. I76.)

Arguments used in the debate made references to both reality and theory. On the one hand, the veterans of the resistance movement claimed that the novel was untruthful when depicting communists as quarrelsome and even deceitful at times, when according to their experience, real communists had been decent and committed to the cause. On the other hand, Peltonen contends that younger Taistoists found that the novel did not meet their ideals of politically conscious literature (Peltonen, 201 5, p. I76).

Milla Peltonen reads mostly male authors writing realist novels, ${ }^{\text {II }}$ and as the quotation above shows, she sees a certain antagonism between them and the Taistoists. This view has, however, been challenged as well. In an anthology published in 2010, I970-luku suomalaisessa kirjallisundessa [The I970s in Finnish Literature], the author Marja-Leena Mikkola points out how little research there is on the variety and width of the oeuvres by authors who took part in the Taistolaiset movement (Mikkola, 20Io, pp. 64-65). Indeed, their support of the movement did not mean that their production was uniform, or their 
worldviews overall dogmatic. Pirkko Saisio, as mentioned in the opening anecdote, was a Taistoist as well. Still, her relationship to class-conscious art as a young writer was reflective rather than didactic, and retrospectively, she has chosen to highlight her bewilderment rather than, for example, satisfaction at being named a working-class author. However, even though the generation of artists that in the I970s became known as Taistoists still have an immense impact on Finnish cultural life, research that would inquire into the specific nature of their input remains largely to be done.

A notable phenomenon with regard to the tradition outlined here is that the Taistoist writers did not necessarily claim to be working-class by birth. However, they sought to redefine and demystify art so that making art could be considered labor. This is signaled even in the name they chose for the union they started in I972, Cultural Workers' Union [Kulttuurityöväen Liitto]. They also sought an organic connection with the workers in the more traditional understanding of the word. For instance, the union published a cultural manifesto in 1975 called Art Belongs to the People [Taide kuuluu kansalle]. Also, they performed in factories and at rallies supporting strikes, their theater groups toured the country, and member Marja-Leena Mikkola wrote one of the most respected document novels in Finnish literary history, called Heavy Cotton [Raskas puuvilla] (I97I). In the novel, she documents the life and working conditions of women employed in the Finnish cotton industry. A significant feature of the Taistoist movement is also that quite a large number of its most prominent writers were women. In addition to those mentioned above, Aulikki Oksanen, for example, was also an important figure, known both as a writer and a popular singer of political songs.

The heated political atmosphere had impacts on the academic world as well, in Finland as well as elsewhere. Democracy in university management was demanded, Marxist reading groups were founded. In the humanities, it suddenly became evident that talking about art was not an innocent undertaking: it had political implications. This can be seen in the works of the influential Marxist critic Pertti Karkama, who began his work during the I970s. Whereas Raoul Palmgren was interested in the history and 
agents of working-class literature, Karkama turned his Marxist apparatus towards the whole of our national literary history. Thus, in his case, it was mostly methodology (not the research material) that signaled class-consciousness. Palmgren had acted as professor of literature at the University of Oulu since I968. In I978, Karkama became his successor.

\section{Working-Class Literature Today}

In this anthology, Magnus Nilsson remarks that the status for, and interest in, working-class literature in Sweden hit its all-time low in the I980s and I990s. In Finland, the pattern is similar but not quite as dramatic. Even after the tumultuous I970s, Pirkko Saisio, Hannu Salama, Marja-Leena Mikkola, and Aulikki Oksanen, among others, carried on writing. The Cultural Worker's Union continued publishing its own magazine, Kulttuurivibkot [The Cultural Notebooks], until I99I. Pertti Karkama continued his Marxist literary studies, attracting many disciples. Kari Sallamaa, the foreman of Kiila [Wedge] (1975-77), began his academic career in the I980s, focusing for example on the legacy of Raoul Palmgren and the history of the first generation of Kiila. However, from the point of view of the I 980 os' self-understanding, working-class literature was not a central phenomenon. Rather, what was regarded as interesting and new was the literature that sought to disavow the values of the I970s. Thus, literature that wanted not to convey clear political messages became the hallmark of the Finnish I980s. Postmodernism and punk were the buzzwords, and even writers who could have, in fact, been read into the working-class continuum (such as Rosa Liksom) rarely were. Instead, fragmentary style and other such features that signaled postmodernism were eagerly pinpointed as the central defining features of the I980s' emerging generation of writers. This paved way for a more determined rejection of the concept of class in public and academic discussions during the early I990s. This rejection expressed the principles of the neoliberal shift taking place in Finland, which argued that social classes did not exist anymore; we were all just individuals (Kauranen \& Lahikainen, 2016, p. 46). 
Since the late I990s, several writers in Finland have once again put class difference under scrutiny. This is the phenomenon which Jussi Ojajärvi (2006; 20I 5 ) refers to as the new emergence of class in Finnish literature. Arto Salminen-as well as Kari Hotakainen, Reko Lundán, Juha Seppälä, Mari Mörö, Outi Alm, and Hanna Marjut Marttila-wrote novels in the context of the neoliberal turn of the I980s and the great economic depression at the beginning of the I990s in Finland. According to Ojajärvi, it was Arto Salminen who wrote, in his six novels, the angriest critique of neoliberal inequality. Salminen politicizes the subjectivities of the working class with aesthetic and literary representations (such as the figure of the dirty class) which are ambivalent in their ironic tone, and modifies the critical ethos of social realism with some naturalist and modernist stylistic influences (Ojajärvi, 20I 5 , pp. I 8 I-I 82 ).

Recently, the revival of literature focusing on class differences and social fragmentation has been joined by research on working-class literature, and Finnish working-class literature has become a topic of lively discussions. In addition, the annual Working-Class Literature Day has been organized in Tampere since $20 \mathrm{IO}$ and another in Helsinki since 20I4. A special issue of the Journal of Finnish Studies published in 2015 (vol. I 8, no. 2), titled "International Influences in Finnish Working-Class Literature and Its Research," constitutes the first ever presentation of Finnish working-class literary tradition in English. It presents the results of the revived interest in this literature from the turn of the twentieth century to the present day.

However, despite the increased interest in working-class literature in Finland in recent years, there is still no agreement on how to define it. Who counts as a working-class writer? Do we still need such a notion? Do contemporary Finnish writers describe themselves as working-class writers? What does the term imply, and what sort of images does it trigger among the writers or readers?

The publisher Robustos presented the poet Hannu Häkli as a "working-class writer from Tampere" on their web page in 2008. When asked why he chose to introduce himself as such, Häkli explained that it was because of his working-class background and the fact that he has trained "to be a so-called worker and 
worked in different so-called working-class trades" (Launis, 20 Iо). Häkli, in other words, links the notion strictly to an author's life and the experience of being a workerworker-much like Pirkko Saisio did. Häkli also said that the notion had surprised readers because his poems do not represent the "communist pathos." Nor are they political comments. According to Mäkijärvi (2008), Häkli moves in spheres that are more sensitive than the "working-class romanticism": in nature, dreams, and affects (Launis, 20IO). Another example of the continuous topicality of the subject comes from the year 2016, when the journalist Asta Leppä asked, in an essay published in Finland's leading newspaper Helsingin Sanomat, whether the middle class has monopolized Finnish literature. She mentions that Arto Salminen's and Hanna-Marjut Marttila's novels are not among the bestsellers of the day and asks, where are the depictions of the working or lower class, poor and marginalized, in Finnish contemporary literature. Where is today's Toivo Pekkanen or Väinö Linna? (Leppä, 20I6).

As we have shown in this article, working-class fiction never simply existed as a reflection of some self-evident class-bound reality. Rather, the history of working-class literature is a history of definitions and counter-definitions; an amalgamation of political and literary histories, national tendencies, and transnational influences; politically motivated wishful thinking; and conventional and convincing portrayals of working people. What has been regarded as "authentic" has throughout this history been represented as something only about to emerge. In this respect, we have travelled far just to arrive where we started: the anticipation of the true working-class poet.

\section{Notes}

I. Mikko Pollari's recent research is a notable exception to this rule. Pollari's starting point is explicitly in transnational theories, and his focus is on transatlantic movements between Finland and the United States in the early twentieth century (see, e.g., Pollari, 20I 5 ). For other openings towards a transnational perspective, see Salmi-Niklander \& Launis, 2015. 
2. Palmgren's two-volume study on the "literature of our old workingclass movement" (as the subtitle of the study reads) was published in 1966. Palmgren's main interest was in cataloguing the whole field. He goes through the oeuvre of every single writer in the field, summarizing the thematics and plotlines and giving as much biographical information about the writers as he possibly can. Palmgren's work is not explicitly theoretical, unless an interest in working-class literature counts as a theoretical starting point per se. Rather, his politics and theoretical commitments are mostly implicit, such as considering the gender-specific nature of working-class women's oppression irrelevant from the point of view of what working-class fiction should depict (Hyttinen, 2015). However, Palmgren's magnum opus remains influential, as he was the first to focus academic interest on working-class writers of the pre-independence era. Palmgren went through an incredible amount of first-hand sources to be able to define the borders of the field, counting and naming the writers he considered as belonging to it.

3. For one example, see Työmies, 23 November I904.

4. The same debate concerned publishers, such as Vihtori Kosonen. See Pollari, 20I 5, pp. 35-55.

5. Magnus Nilsson has stressed the point that the existence of the tradition of working-class writing in Sweden has given writers legitimacy for the production of subaltern, radical discourses on class. For this reason, he argues that the tradition is always in conflict with hegemonic discourses (such as nationalism), which attempt to deny the significance of class or, in the case of more recent discourses, the common view that class distinctions no longer exist (Nilsson, 20I I, pp. 199-208).

6. It has, however, been claimed that the formation of red troops had more to do with local conflicts between the landed gentry and the landless poor, and that the will to fight was not necessarily motivated with any awareness of class as a larger structure (Ylikangas, I993, pp. 8-20).

7. The Wikipedia article on the Finnish Civil War offers a research-based summary of the events of the Civil War in English: https://en.wikipedia.org/wiki/Finnish_Civil_War

8. Tehtaan varjossa tapped into an internationally popular trend in working-class literature. In Scandinavia, especially in Sweden, writers 
such as Ivar Lo-Johansson, Eyvind Johnson, Jan Friedgård, Harry Martinson, and Gustav Sandgren published a set of autobiographical Bildungsromane in the I930s. Even though Pekkanen was probably well aware of these novels, the most influental model for him was still Jack London's Martin Eden. (see Pynttäri, 20 I 5, p. I32). Martin Eden was an important source of inspiration for the Swedish workingclass writers, too (see Magnus Nilsson's chapter in this book).

9. Here, Linna is playing with a Finnish proverb that says "a dear child has many names," which means (approximately) that people can appreciate the same thing even if they use different words for describing it.

Iо. In Finnish press, the terms työväenkirjailija and työväenkirjallisuus (not työläiskirjailija) seem to be the original terms used by the contemporaries at the turn of the twentieth century. These terms convey the meaning of a "working-class author" and the "working-class literature", as in an author writing to workers as opposed to literature written for workers. In this sense, the original term in Finland refers more to the readership than to the roots and social class of the author (as emphasized later by Palmgren).

I I. Peltonen studies the works of Hannu Salama, Alpo Ruuth, Lassi Sinkkonen, Samuli Paronen, and Jorma Ojaharju as the most prominent working-class writers of the era. She isolates two very different ways they relate to the realist working-class tradition of prose preceding them. Some of them carry on with the realist tradition without problematizing it-with an omniscient narrator, orderly and integrated plot, and portrayals of individuals as members of a group. Alpo Ruuth, for example, would fit this continuum (Peltonen 2015, p. I68). Others question precisely those founding blocks that stabilize a traditionally realist fictional rendition, such as the narrator's omnipotence and the causal integrity of the plot (ibid., pp. I68-I69), thus remodelling the realist tradition. In postrealist novels, the act of writing is often depicted and, through such depictions, the questions of representability, narratability, and politics of writing are made visible within the narrated world. The breakthrough, argues Peltonen, of postrealism in Finnish literature takes place in the novel Siinä näkijä missä tekijä, in which the narration itself becomes a notable part of the action depicted (Peltonen, 20I 5, p. I69; Peltonen, 2008, pp. 49-53). In this respect, working-class fiction of the I970s could be seen as making way to the postmodernist experimentality of the I980s. 


\section{References}

Haapala, P. (I999). Työväenluokan synty. In: P. Haapala, ed., Talous, valta ja valtio: Tutkimuksia I80o-luvun Suomesta. Tampere, Vastapaino, pp. I99-2 I9.

Hitchcock, P. (1989). Working-Class Fiction in Theory and Practice. A Reading of Alan Sillitoe. Ann Arbor, UMI Research Press.

Hyttinen, E. (2004). Kuinka Pirkko Saisio tehdään? Naiskirjailijuus performatiivisena identiteettinä. University of Helsinki, Finnish literature (MA thesis, unpublished).

Hyttinen, E. (2012). Kovaa työtä ja kohtalon oikkuja. Elvira Willmanin kamppailu työläiskirjallisuuden tekijyydestä vuosisadanvaibteen Suomessa. Turku, University of Turku

Hyttinen, E. (20 I 5). Women in Early Capitalism and Other Irrelevant Issues: Elvira Willman's Struggle for Working-Class Authorship. Journal of Finnish Studies 2, pp. 56-74.

Hyttinen, E. and Salmi-Niklander, K. (2008). Nainen näkinkengässä. Naistutkimus-Kvinnoforskning I, pp. 56-6I.

Kaatra, K. (I924). Äiti ja poika: Kuvaus köybäinkorttelista. Helsinki: Osakeyhtiö Työn kirjapaino.

Kauranen, K. (2013). Odd Man out? The Self-educated Philosopher and his Analyses of I9th-century Finland. In: A. Kuismin \& M. Driscoll, eds., White Field, Black Seeds: Nordic Literacy Practices in the Long Nineteenth-Century. Studia Fennica Litteraria 7. Helsinki, Finnish Literature Society, pp. I 20-I34.

Kauranen, R. and Lahikainen, L. (20I6). Luokan äänen ja hiljaisuuden muodostuminen rakenteellisesti ja kokemuksellisesti. In: A. Anttila, R. Kauranen, K. Launis and J. Ojajärvi, eds., Luokan ääni ja hiljaisuus. Yhteiskunnallinen luokkajärjestys 200o-luvun alun Suomessa. Tampere, Vastapaino, pp. 46-87.

Kettunen, P. (I990). Politiikan menneisyys ja poliittinen historia. In: Ahtiainen et al eds., Historia nyt. Helsinki, WSOY, I63-207.

Klaus, G. (I985). Literature of Labour. New York, St. Martin's Press.

Koivisto, H. (20I 5). Devotedly International - But Always Wrong: Left-Wing Intellectuals and Their Orientation toward International 
Progressive Culture and Literature in the I930s and I940s. Journal of Finnish Studies 2, pp. 99-I 24.

Koskela, L. (I999). Kansa taisteli - valkoiset kertoivat. In: L. Rojola, ed., Suomen kirjallisuushistoria 2. Järkiuskosta vaistojen kapinaan. Helsinki, Finnish Literature Society, pp. 222-235.

Kotilainen, S. (2016). Literary Skills as Local Intangible Capital: The History of a Rural Lending Library c. I860-1920. Helsinki, Finnish Literature Society.

Kuismin, A. (2016). Ploughing with the Pen. Metapoetic Elements in Finnish Nineteenth-Century Peasant Poetry. In: A. Edlund, T. G. Ashplant, A. Kuismin, eds., Reading and Writing from Below: Exploring the Margins of Modernity. Umeå, Umeå University \& Royal Skyttean Society, pp. 9-24.

Lahtinen, M. (2006). Snellmanin Suomi. Tampere, Vastapaino.

Lappeenrannan Uutiset July I7, I 895. Työväenkalenteri III.

Launis, K. (2009). Työväen Maamme-kirja. In: K. Melkas, H. Grönstrand, K. Launis, M. Leskelä-Kärki, J. Ojajärvi, T. Palin, and L. Rojola, eds., Läpikulkuibmisiä: Muotoiluja kansallisuudesta ja sivistyksestä I900-luvun alun Suomessa. Helsinki, Finnish Literature Society, pp. 73-106.

Launis, K. (2010). Työväenkirjallisuus ennen ja nyt. Kiiltomato [online] 4.5.20I0. Available at: http://www.kiiltomato.net/ tyovaenkirjallisuus-ennen-ja-nyt/ [Accessed 7 Dec. 20I6].

Launis, K. (20I5). The Making of the Finnish Working Class in Early Twentieth-Century Working-Class Literature. Journal of Finnish Studies 2, pp. 14-34.

Leppä, A. (20I6). Passiivisuutta, ongelmien välttelyä, silmien ummistamista - onko keskiluokka ominut kirjallisuuden? Helsingin Sanomat July 26, 2016.

Linna, V. (I 990). Murroksia. Esseitä, puheita ja kirjoituksia. Helsinki, WSOY.

Luukkanen, T. (2016). Mitä maalaiskansa luki? Kirjasto, kirjat ja kirjoja lukeva yhteisö Karstulassa I86I-I9I8. Helsinki, Finnish Literature Society. 
Mikkola, M. (20ı). Mitä sanottavaa minulla on pahasta 70-luvusta. In: K. Hypén, ed., I970-luku suomalaisessa kirjallisuudessa. Helsinki, Avain.

Mäkijärvi, E. (2008). Seuraamisen arvoista runoutta. Kiiltomato [online] I 5 Dec. 2008. Available at: http://www.kiiltomato.net/hannuhakli-seuraajat/ [Accessed 7 Dec. 20I6].

Nieminen, H. (2006). Kansallisen julkisuuden rakentuminen Suomessa I 809-19I7. Tampere, Vastapaino.

Niemi, J. (I999). Kirjallisuus ja sukupolvikapina. In: P. Lassila, ed., Suomen kirjallisuushistoria 3. Rintamakirjeistä tietoverkkoibin. Helsinki, Finnish Literature Society, pp. I 58-I7 I.

Nilsson, M. (20II). Arbetarlitteratur, teori, politik: Utkast till ett marxistiskt program för forskning och undervisning om svensk arbetarlitteratur. In: B. Jonsson, M. Nilsson, B. Sjöberg, and J. Vulovic, eds., Från Nexø till Alakoski: Aspekter på nordisk arbetarlitteratur. Lund, Absalon förlag, pp. I99-208.

Nummi, J. (I999). Väinö Linnan klassikot. In: P. Lassila, ed., Suomen kirjallisuushistoria 3. Rintamakirjeistä tietoverkkoibin. Helsinki, Finnish Literature Society, pp. 99-IO2.

Ojajärvi, J. (2006). Supermarketin valossa: Kapitalismi, subjekti ja Minuus Mari Mörön romaanissa Kiltin yön lahjat ja Juha Seppälän novellissa "Supermarket". Helsinki: Finnish Literature Society.

Ojajärvi, J. (2OI 5). The Dirty Class: The Re-intensified Antagonism of Capital and Labor, and the Politics of Arto Salminen. Journal of Finnish Studies 2, pp. I 8 I-209.

Ojajärvi, J. (forthcoming). Work as a Socially and Politically Invested Figure in Finnish Literature. In: L. Haverty Rugg and K. Sanders, eds., Nordic Literary History 3.

Palmgren, R. (I965). Työläiskirjallisuus. (Proletaarikirjallisuus.) Käsite- ja aatehistoriallinen käsiteselvittely. Helsinki, WSOY.

Palmgren, R. (I966 a \& b). Joukkosydän. Vanhan työväenliikkeemme kaunokirjallisuus I-II. Helsinki, WSOY.

Peltonen, M. (2008). Jälkirealismin ehdoilla: Hannu Salaman Siinä näkijä missä tekijä ja Finlandia-sarja. Turku, Uiversity of 
Turku. Available at: http://urn.fi/URN:ISBN:978-95 I-29-3658-8 [Accessed 7 Dec. 2016].

Peltonen, M. (201 5). Reshaping FinnishWorking-Class Prose: Hannu Salama's Siinä näkijä missä tekijä as a Postrealistic Novel. Journal of Finnish Studies 2, pp. I66-1 80.

Pollari, M. (2015). The Literally International Adventures of Vihtori Kosonen. Journal of Finnish Studies 2, pp. 35-55.

Pynttäri, V. (201 5). Recognizing Your Class - Toivo Pekkanen, Raoul Palmgren, and Literature for the Working Class. Journal of Finnish Studies 2, pp. I25-I43.

Roininen, A. (I993). Kirja liikkeessä: Kirjallisuus instituutiona vanhassa työväenliikkeessä (I895-I9I8). Helsinki, Finnish Literature Society.

Roininen, A. (I999). Työväenliike tuo työläiset kirjallisuuden kentälle. In: Lea Rojola, ed., Suomen kirjallisuushistoria 2. Järkiuskosta vaistojen kapinaan. Helsinki, Finnish Literature Society, pp. 92-I05.

Rojola, L. (2009). Sivistyksen ihanuus ja kurjuus-suomalaisen nousukkaan tarina. In: K. Melkas H. Grönstrand, K. Launis, M. LeskeläKärki, J. Ojajärvi, T. Palin, and L. Rojola, eds., Läpikulkuibmisiä: Muotoiluja kansalaisuudesta ja sivistyksestä I90o-luvun alun Suomessa. Helsinki, Finnish Literature Society, pp. Iо-38.

Saisio, P. (2000). Pirkko Saisio. In: R. Haavikko, ed., Miten kirjani ovat syntyneet 4 . Helsinki, WSOY, pp. 336-367.

Saisio, P. (I976). Pirkko Saision itsetilitys: odotamme yhä suurta työläiskirjaijaa. Suomen kuvalehti 2.

Salmi-Niklander, K. (20I0). Sanelman sisaret: Sosiaalisen tekijyyden strategioita nuorten työläisnaisten suullis-kirjallisissa verkostoissa I9 Io-20-luvulla. In: I. Kemppainen, K. Salmi-Niklander, and S. Tuomaala, eds., Kirjoitettu nuoruus: Aikalaistulkintoja I90oluvun alkupuolen nuoruudesta. Helsinki, Finnish Youth Research Society, 20-46.

Salmi-Niklander, K. \& Launis, K. (2015). New Research Trends in Finnish Working-Class Literature: Introduction. Journal of Finnish Studies 2, pp. 3-I3. 
94 Working-Class Literature(s): Historical and International Perspectives

Seppälä, M. (20Iо). Suomalaisen työväenteatterin varhaisvaiheet. Helsinki, Finnish Literature Society.

Turtiainen, A. (I937). Kiilan albumi, pp. 6-I I.

Työmies November, 23, I904. Uuden ajan kynnyksellä.

Valpas, E. (1904). Työväen laulaja. Työmies April 6-7, I904.

Varpio, Y. (2006). Väinö Linnan elämä. Helsinki, WSOY.

[No title.] Vasabladet September 22, I903.

Ylikangas, H. (1993). Tie Tampereelle. Helsinki, WSOY. 